\title{
CARBON DIOXIDE AND THE WORK OF BREATHING*
}

\author{
BY JOHN C. PARKER, RICHARD M. PETERS, AND THOMAS B. BARNETT \\ (From the Departments of Medicine and Surgery, The University of North Carolina School of \\ Medicine, North Carolina Memorial Hospital, Chapel Hill, N. C.)
}

(Submitted for publication April 30, 1962; accepted May 2, 1963)

It is well-known that within certain concentration limits carbon dioxide increases the work of breathing simply by acting on the respiratory center to stimulate hyperventilation. There is evidence that $\mathrm{CO}_{2}$ also affects work of breathing by virtue of its tendency to cause bronchoconstriction with increased airway resistance.

Einthoven (1) demonstrated in dogs ventilated with a pump that end-inspiratory pressure increased when the gas mixture ventilating the lungs contained high concentrations of $\mathrm{CO}_{2}$. Dixon and Brodie (2) found that when animals were similarly ventilated with gases containing high concentrations of $\mathrm{CO}_{2}$, the expiratory phase was prolonged and the lungs trapped air. They noted that vagotomy prevented these changes. Daly, Lamberton, and Schweitzer (3) studied the resistance to inflation of the lungs in cross-circulation experiments in which the blood returning from one dog's lungs was used to perfuse another dog's brain. They demonstrated that an animal whose brain received blood with a high $\mathrm{pCO}_{2}$ developed increased resistance to lung inflation as determined by the method of Konsett and Rossler (4). Peters (5), using the same method, showed that the increase in resistance to lung inflation was proportional to arterial $\mathrm{pCO}_{2}$ when dogs were ventilated with gases with high $\mathrm{CO}_{2}$. Atropine and vagotomy prevented these changes.

These studies showed that $\mathrm{CO}_{2}$ affected lung mechanics, but gave no information about whether the change was in the elastic or viscous (flowresistive) properties of the lung. Roy and Brown in 1885 (6) found that the pressure in an endobronchial balloon increased with asphyxia, presumably owing to bronchoconstriction; vagotomy prevented this increase. Kilburn (7) demonstrated with bronchograms that inhalation of $5 \%$ $\mathrm{CO}_{2}$ decreased the bronchial diameter by $15 \%$.

* This work was supported by U. S. Public Health Service grant H-1257.
These last two studies suggest that the alteration in pulmonary mechanics associated with $\mathrm{CO}_{2}$ breathing is due to bronchoconstriction with increased airway resistance. In contrast, in isolated perfused lungs, Nisell (8) and others have shown that increased $\mathrm{CO}_{2}$ in the ventilating gas causes bronchodilatation.

Attinger (9) measured the pulmonary compliance, transpulmonary resistance, and functional residual capacity in dogs with an esophageal balloon to measure intrathoracic pressure and a plethysmograph to determine the flow and volume changes. With administration of 5 and $10 \% \mathrm{CO}_{2}$, minute volume increased and functional residual capacity decreased, but the changes in compliance and resistance were not considered significant. Butler, Caro, Alcala, and DuBois (10), using DuBois's closed-plethysmograph method in humans, found that ventilation with 4 to $10 \% \mathrm{CO}_{2}$ caused no change in airway resistance.

We undertook this investigation to determine more specifically the nature of the effects of hypercapnia on respiratory mechanics and the work of breathing.

\section{METHODS}

In order to determine the effect of $\mathrm{CO}_{2}$ on the mechanical properties of the lung alone, the other effects of $\mathrm{CO}_{2}$ had to be controlled. Any method allowing the animals to breathe spontaneously during $\mathrm{CO}_{2}$ administration would inevitably lead to an alteration in the rate and depth of respiration. If the position or depth of respiration were altered, the end-inspiratory or end-expiratory volume might be outside the range of linear pressurevolume relationship. This would cause an apparent change in compliance without any actual change in the elastic properties of the lung. Changes in lung volume and in the rate of air flow would also introduce uncontrollable variations in airway resistance due to changes in bronchial caliber and in the ratio of turbulent to laminar flow. The use of controlled respiration in animals given muscle-paralyzing agents was unsatisfactory, since these agents cause an increase in bronchial secretions unless atropine or atropine-like drugs are given. Therefore, 
the best method available was measurement of pulmonary mechanics in experimental animals with lungs exposed at thoracotomy and ventilation at all times carefully controlled by respirator pump. A pump was constructed to withdraw at all times exactly the volume of gas delivered without causing the animal to rebreathe its own expired gas. ${ }^{1}$ The pump was equipped with two solenoid valves so timed that during one pump cycle, the animal was ventilated and during the next, the pump was evacuated and refilled. Thus, there was a pause equal to one respiratory cycle at the end of each expiration and no inspiratory pause. The tidal volume of this pump could be varied from 0 to $1,000 \mathrm{ml}$, and the frequency, from 0 to 22 respiratory cycles per minute. The inspiratory and expiratory flow rates could be controlled independently. Signals for volume and flow rate were generated respectively by a potentiometer and generator attached to the piston of the pump. The accuracy of the volume and flow measurements made with this respirator was checked by recording the flow rate simultaneously with a parallel plate flow resistor (linear range, 0 to $100 \mathrm{~L}$ per minute). Across this was connected a Statham \pm 0.05 pounds per inch $^{2}$ differential manometer. The signal from this flowmeter was electronically integrated to give volume. Conditions occurring in most of these experiments were then simulated, and recordings made and analyzed. The discrepancy in time between the volume and flow measurements recorded by the pump and those by the flow integrator system was never greater than 0.03 seconds. Plots of data made from both recording systems coincided almost exactly when superimposed. Although this pump was designed to withdraw at all times exactly the volume delivered, it still did not assure maintenance of the same lung volume. In a system of this type, any deviation of $R Q$ from unity might be expected to cause a progressive change in the lung volume over the course of the experiment. When a gas mixture high in $\mathrm{CO}_{2}$ is administered to a previously normocapnic animal, one might expect an acute decrease in $R Q$, as $\mathrm{CO}_{2}$ accumulates in the animal's tissues, until equilibrium is attained. The opposite effect would be expected on return to room air. Since the pressure in the pump during inspiration and expiration would not be exactly the same, it was also possible for this to cause the lungs to change volume. This would occur because the pump would fill itself at atmospheric pressure and force this air into the animal's lungs at an increased pressure; then it would withdraw air at less than atmospheric pressure and refill at atmospheric pressure. To detect changes in volume due to any of these factors, a total-body plethysmograph was used in some of the experiments as described below.

Mongrel dogs weighing between 8 and $16 \mathrm{~kg}$ were anesthetized with intravenous chloralose, $125 \mathrm{mg}$ per $\mathrm{kg}$. In one instance, pentobarbital was used instead. Each dog was placed on its back, and a large, curved, tracheostomy tube tied securely into the cervical trachea. A mid-line sternotomy was then carried out with electrocautery to

\footnotetext{
${ }^{1}$ Custom Engineering \& Development Co., St. Louis, Mo.
}

control bleeding and the Stryker saw to divide the sternum. The tracheal cannula was connected to the pump) described above just before the chest was opened. The two edges of the sternum were widely retracted with the rib spreader, and both phrenic nerves clamped and divided. In those experiments in which the vagus nerve was to be stimulated, the carotid sheath in the neck was opened, and the nerve was isolated so that it could be divided and its distal end stimulated electrically. The femoral artery was exposed and cannulated with a polyethylene catheter, which was attached to a 3-way stopcock so that blood samples could be withdrawn and blood pressure monitored with a Statham P23D manometer. Transpulmonary pressure was measured with a Statham \pm 2 pounds per inch ${ }^{2}$ differential manometer. One chamber of this instrument was connected to the tracheal cannula, and the other was left open to the atmosphere. The volume, transpulmonary pressure, flow rate, and blood pressure were all suitably amplified and simultaneously recorded on an Offner multichannel recorder. The manometer used to measure airway pressure was calibrated against water after each experimental period. Cervical vagotomy was done in two of the dogs, and the vagus was stimulated with a Harvard apparatus stimulator using $15 \mathrm{v}$ at 100 cycles per second.

In five studies, once the chest had been opened and the lungs exposed, the dogs were placed in an airtight, 50gallon plethysmograph. When thermal equilibrium was reached, the plethysmograph was sealed, and gains or losses in the dog's lung volume were recorded as pressure changes in the plethysmograph with a Statham \pm 0.15 pounds per inch ${ }^{2}$ manometer. In experiments with the plethysmograph, transpulmonary pressure was measured as the difference between the pressure in the airway and that within the plethysmograph.

In these experiments, after the operative procedure, the position, rate, and volume of respiration were adjusted so that the lungs seemed to be in a normal mid-position and not over- or underinflated. After all adjustments, volume, flow rate, transpulmonary pressure, plethysmographic pressure, and blood pressure were recorded with the dog breathing air. Three to four complete respiratory cycles were included. The time of this first reading was that from which all times noted in Tables I and II were calculated. The test gas-25\% $\mathrm{O}_{2}, 10$ to $20 \%$ $\mathrm{CO}_{3}$, and nitrogen to make $100 \%$-was then administered for 3 to 10 minutes, and recordings were repeated once or more during this period, usually at 3-minute intervals. The dog was then ventilated with air long enough to allow arterial $\mathrm{pCO}_{2}$ to return to normal. Recordings were repeated, and then another test gas administered. Samples of arterial blood were drawn within 30 seconds of each recording. Oxygen saturation was determined with a Waters double-scale oximeter, total $\mathrm{CO}_{2}$ with a Van Slyke-Neill apparatus, and $\mathrm{pH}$ with a radiometer $\mathrm{pH}$-meter at $37.5^{\circ} \mathrm{C}$. $\mathrm{pCO}_{2}$ was calculated from the Henderson-Hasselbalch equation after correction of $\mathrm{pH}$ and $\mathrm{pK}$ to the dog's temperature.

From those recordings, graphs were drawn with transpulmonary pressure plotted against the volume of gas in 
the lungs above end-expiratory level. Resistance was computed as the difference between the inspiratory and expiratory transpulmonary pressure at half tidal volume divided by the sum of the flow rates at these two points by the method of Cook and co-workers (11). Compliance was determined in all experiments from the slope of the line drawn between maximal and minimal volume points on the dynamic pressure-volume loop. In some of the experiments, compliance was also measured by stopping the pump for brief periods during inflation. In this way static presure-volume points were obtained. Calculations of resistance and work were made for two or three successive breaths. Values for both work and resistance were reproducible to one part per hundred or better for these two or three, consecutive, controlled, respiratory cycles. The elastic work of breathing was calculated by measurement of the area of the triangle $\mathrm{ABC}$ in Figure $1 \mathrm{~A}$, and the viscous work, from the dotted and crosshatched area enclosed by the loop.

The effect of changes in end-expiratory volume was also determined. Withdrawal of gas from the system increased the measured nonelastic resistance and work. Conversely, addition of gas to the end-expiratory lung volume decreased measured nonelastic resistance and work. Therefore, if the volume decreased significantly during $\mathrm{CO}_{2}$ breathing, increase in measured nonelastic resistance and work presumably could be the result of decrease in lung volume alone. An increase in endexpiratory volume, however, might obscure, but could not enhance an increase in nonelastic resistance and work.
RESULTS

Pulmonary compliance, resistance, and elastic and viscous work were determined in 10 dogs 32 times while the dogs breathed air and 40 times while they breathed $\mathrm{CO}_{2}$ mixtures. Throughout all experiments in the study, blood pressure and heart rate remained within normal limits. A 5to $10-\mathrm{mm}$ increase in mean blood pressure and slight bradycardia were observed in some of the dogs ventilated with gases containing high percentages of $\mathrm{CO}_{2}$. Figure 1 shows typical plots before and after the administration of $\mathrm{CO}_{2}$.

Table I presents the results of measurements of resistance, compliance, and elastic and nonelastic work in the five initial experiments in which dogs were ventilated with air and with various concentrations of $\mathrm{CO}_{2}$. Arterial $\mathrm{pCO}_{2}$ was determined at the times shown. The transpulmonary pressure at the end-expiratory point is shown in the column on the far right. Values for $\mathrm{CO}_{2}$ breathing in most instances are the average of two values a few minutes apart. For the statistical analysis reported below, all values were independently analyzed, but are averaged in this table for brevity, since the differences were insignificant.

Tidal Vol.

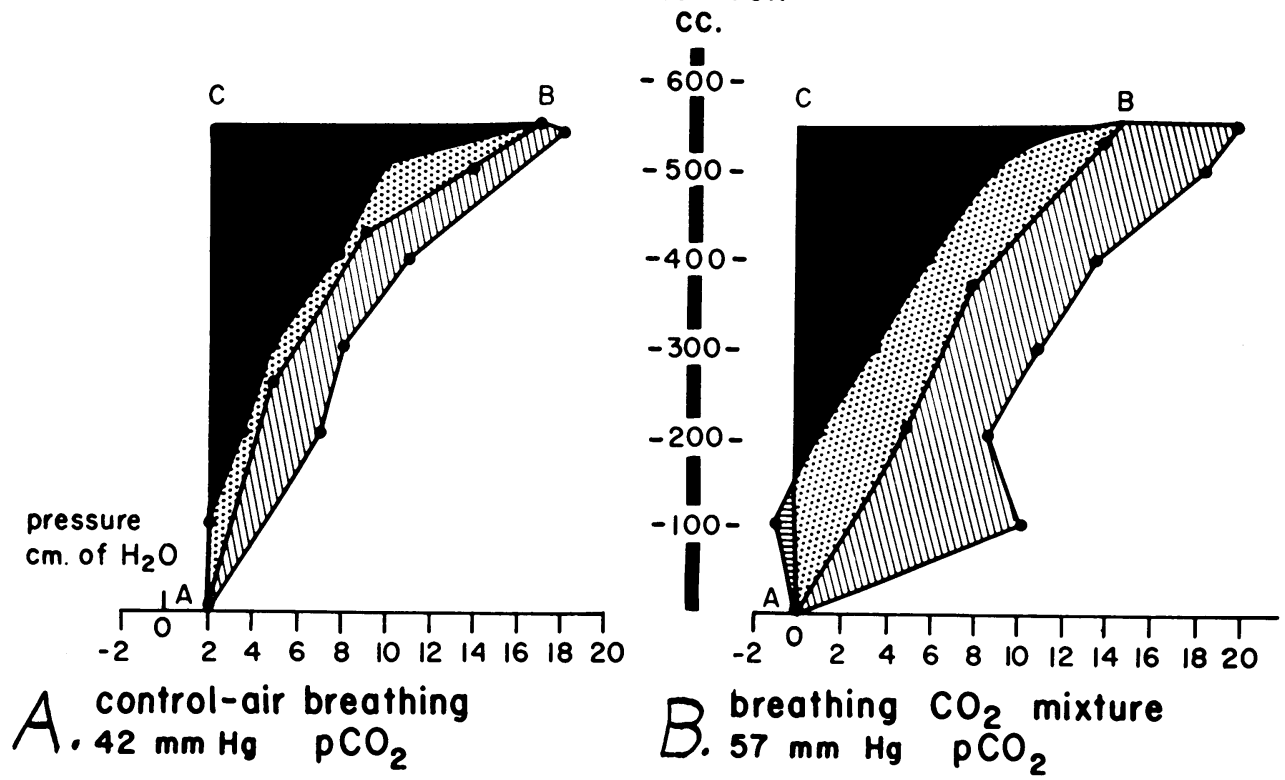

Fig. 1. Measurements in dogs breathing A) air (control) and B) CO.z mixtures. 
TABLE I

Measurements in dogs ventilated with air and with $\mathrm{CO}_{2}{ }^{*}$

\begin{tabular}{|c|c|c|c|c|c|c|c|c|c|}
\hline Dog & TTG & $\mathrm{T}_{\mathrm{p}} \mathrm{C}$ & $\begin{array}{l}\text { Test } \\
\text { gas }\end{array}$ & $\underset{\mathrm{pCO}_{2}}{\text { Arterial }}$ & Resistance & Compliance & $\begin{array}{c}\text { Nonelastic } \\
\text { work }\end{array}$ & $\begin{array}{c}\text { Elastic } \\
\text { work }\end{array}$ & $\begin{array}{l}\text { Transpulm. } \\
\text { end-expir. } \\
\text { pressure }\end{array}$ \\
\hline & $\min$ & $\min$ & $\% \mathrm{CO}_{2}$ & $m m \mathrm{Hg}$ & $\underset{L / \mathrm{sec}}{\mathrm{cm} \mathrm{H}_{2} \mathrm{O} /}$ & $\begin{array}{c}m l / c m \\
\mathrm{H}_{2} \mathrm{O}\end{array}$ & $\begin{array}{c}\text { dyne-cm } \\
\times 10^{6}\end{array}$ & $\begin{array}{c}\text { dyne-cm } \\
\times 10^{6}\end{array}$ & $\mathrm{~cm} \mathrm{H}_{2} \mathrm{O}$ \\
\hline 1 & $\begin{array}{r}15 \\
10 \\
10 \\
5 \\
5\end{array}$ & $\begin{array}{r}0 \\
19 \\
29 \\
35 \\
45\end{array}$ & $\begin{array}{l}\text { Air } \\
15 \\
\text { Air } \\
20 \\
\text { Air }\end{array}$ & $\begin{array}{r}24 \\
116 \\
28 \\
151 \\
29\end{array}$ & $\begin{array}{r}5.19 \\
12.80 \\
5.37 \\
13.33 \\
3.85\end{array}$ & $\begin{array}{l}39 \\
28.7 \\
33.0 \\
33.0 \\
34.9\end{array}$ & $\begin{array}{l}2.67 \\
6.95 \\
2.84 \\
6.75 \\
1.92\end{array}$ & $\begin{array}{l}4.08 \\
5.25 \\
4.49 \\
4.62 \\
4.14\end{array}$ & \\
\hline 2 & $\begin{array}{r}15 \\
10 \\
16 \\
9 \\
10 \\
12 \\
10\end{array}$ & $\begin{array}{r}0 \\
12 \\
28 \\
40 \\
52 \\
67 \\
80\end{array}$ & $\begin{array}{l}\text { Air } \\
15 \\
\text { Air } \\
15 \\
\text { Air } \\
20 \\
\text { Air }\end{array}$ & $\begin{array}{r}33 \\
104 \\
29 \\
102 \\
26 \\
127 \\
27\end{array}$ & $\begin{array}{r}9.76 \\
13.33 \\
8.54 \\
13.56 \\
4.94 \\
10.14 \\
6.52\end{array}$ & $\begin{array}{l}21.4 \\
23.1 \\
23.0 \\
22.8 \\
26.3 \\
26.8 \\
25.4\end{array}$ & $\begin{array}{l}3.90 \\
4.82 \\
2.98 \\
4.80 \\
1.73 \\
3.52 \\
1.82\end{array}$ & $\begin{array}{l}6.69 \\
5.87 \\
5.81 \\
5.61 \\
5.26 \\
4.69 \\
5.98\end{array}$ & \\
\hline 3 & $\begin{array}{r}15 \\
9 \\
10 \\
3 \\
10 \\
9 \\
9\end{array}$ & $\begin{array}{r}0 \\
10 \\
21 \\
26 \\
37 \\
53 \\
64\end{array}$ & $\begin{array}{l}\text { Air } \\
15 \\
\text { Air } \\
20 \\
\text { Air } \\
10 \\
\text { Air }\end{array}$ & $\begin{array}{r}25 \\
96 \\
27 \\
129 \\
33 \\
82\end{array}$ & $\begin{array}{l}2.58 \\
8.16 \\
1.62 \\
9.18 \\
1.26 \\
7.02 \\
1.62\end{array}$ & $\begin{array}{l}51.6 \\
38.9 \\
44.7 \\
39.5 \\
51.6 \\
42.7 \\
44.7\end{array}$ & $\begin{array}{r}1.67 \\
6.14 \\
1.33 \\
6.96 \\
.94 \\
5.34 \\
1.22\end{array}$ & $\begin{array}{l}5.51 \\
6.26 \\
5.90 \\
6.43 \\
5.59 \\
6.12 \\
6.41\end{array}$ & $\begin{array}{l}3.0 \\
0.0 \\
2.0 \\
0.0 \\
3.0 \\
0.0 \\
3.0\end{array}$ \\
\hline 4 & $\begin{array}{c}15 \\
10 \\
1 \\
10 \\
10 \\
10 \\
3 \\
8 \dagger \\
10\end{array}$ & $\begin{array}{r}0 \\
13 \\
15 \\
24 \\
35 \\
45 \\
49 \\
54 \\
64\end{array}$ & $\begin{array}{l}\text { Air } \\
10 \\
\text { Air } \\
\text { Air } \\
20 \\
\text { Air } \\
15 \\
15 \dagger \\
\text { Air }\end{array}$ & $\begin{array}{r}16 \\
57 \\
42 \\
19 \\
125 \\
21 \\
94 \\
\\
20\end{array}$ & $\begin{array}{l}2.76 \\
9.90 \\
3.42 \\
1.74 \\
6.81 \\
3.48 \\
4.62 \\
3.42 \\
2.98\end{array}$ & $\begin{array}{l}30.0 \\
28.5 \\
33.7 \\
30.0 \\
30.9 \\
32.7 \\
30.0 \\
33.8 \\
33.8\end{array}$ & $\begin{array}{l}1.55 \\
4.92 \\
1.96 \\
1.47 \\
3.43 \\
1.37 \\
2.65 \\
1.59 \\
1.53\end{array}$ & $\begin{array}{l}6.84 \\
6.41 \\
5.81 \\
6.94 \\
6.18 \\
5.96 \\
6.61 \\
6.04 \\
6.32\end{array}$ & $\begin{array}{l}3.0 \\
0.0 \\
2.0 \\
3.0 \\
1.0 \\
2.0 \\
0.0 \\
1.0 \\
1.0\end{array}$ \\
\hline 5 & $\begin{array}{r}15 \\
3 \\
4\end{array}$ & $\begin{array}{c}2 \\
8 \\
13.5\end{array}$ & $\begin{array}{l}\text { Air } \\
10 \\
\text { Air }\end{array}$ & $\begin{array}{l}20 \\
61 \\
20\end{array}$ & $\begin{array}{l}2.34 \\
3.30 \\
2.34\end{array}$ & $\begin{array}{l}55.0 \\
62.5 \\
52.0\end{array}$ & $\begin{array}{l}1.31 \\
2.06 \\
1.51\end{array}$ & $\begin{array}{l}6.39 \\
5.59 \\
7.02\end{array}$ & $\begin{array}{l}4 \\
4 \\
4.5\end{array}$ \\
\hline
\end{tabular}

* TTG $=$ time dog breathed test gas, and $\mathrm{T}_{\mathrm{p}} \mathrm{C}=$ time elapsed since initial control study.

$\dagger$ Atropine, $0.03 \mathrm{mg}$ per $\mathrm{kg}$, iv, 4 minutes before this determination.

With very few exceptions, the viscous resistance and nonelastic work were considerably higher with $\mathrm{CO}_{2}$ breathing and with the resulting hypercapnia than when the dog was ventilated with air. The few exceptions and those instances where viscous resistance was slightly to moderately elevated tended to occur late in the experiments. Simple inspection of the data shows no striking or obvious change in compliance or elastic work. The endexpiratory transpulmonary pressure decreased in all experiments with $\mathrm{CO}_{2}$ breathing.

Table II shows results in studies where changes in end-expiratory volume were determined by making all measurements with the dog in a body plethysmograph. In $\operatorname{dog} 7$, where changes in viscous resistance were smaller than in any other experiment, there was a slight fall in end-expiratory volume.' In all other experiments where changes in mechanics were similar to those presented in Table $\mathrm{I}$, the end-expiratory volume increased after a transient fall when $\mathrm{CO}_{2}$ was administered. As in the initial studies, this was associated with a fall in end-expiratory transpulmonary pressure.

Table III shows the results of one of a number of studies in which vagal interruption was followed by vagal stimulation. Ten per cent $\mathrm{CO}_{2}$ was associated with a threefold increase in nonelastic work, and vagotomy returned this to normal. Vagal stimulation increased the nonelastic work in a manner similar to $\mathrm{CO}_{2}$ with the exception that end-expiratory pressure rose. 
One experiment (not included in tables) was done on a 20-pound pig. Changes in respiratory mechanics were similar to those observed in dogs.

To test the significance of the changes in mechanics of breathing with hypercapnia, data were subjected to statistical analysis. These rather elaborate analyses were necessary to determine the relation between changes in lung mechanics and the arterial $\mathrm{pCO}_{2}$, and to determine whether this was affected by the time on any given test gas and the total duration of the experimental period. This type of analysis also served to correct for the unavoidable variations among dogs.

Data were analyzed by means of four model equations taking each index of lung mechanics (resistance, compliance, and viscous and elastic work) as a dependent variable and assuming each to be a linear function of the effect of the individual dog plus the differing combination of the following three independent variables: arterial $\mathrm{pCO}_{2}$ $\left(\mathrm{pCO}_{2}\right)$, the time in minutes the dog had been breathing the test gas (TTG), and the time in minutes elapsed since the initial control study $(\mathrm{TpC})$. Combinations of the independent variables included each term as well as its square and logarithm to measure quadratic effects and deviations from pure linearity. Individual terms were also combined by multiplication to discover the importance of interactions among the independent variables. Each equation included a parameter to measure the effect of the individual dog. This has the effect of considering each observation as a change in the individual dog and allows the individual variation among the dogs to be removed

TABLE II

Measurements in ventilated dogs in a whole-body plethysmograph*

\begin{tabular}{|c|c|c|c|c|c|c|c|c|c|c|}
\hline Dog & TTG & $\mathrm{T}_{\mathrm{p}} \mathrm{C}$ & $\begin{array}{l}\text { Test } \\
\text { gas }\end{array}$ & $\begin{array}{c}\text { Arterial } \\
\mathrm{pCO}_{2}\end{array}$ & Resistance & Compliance & $\begin{array}{c}\text { Nonelastic } \\
\text { work }\end{array}$ & $\underset{\text { work }}{\text { Elastic }}$ & $\begin{array}{l}\text { Transpulm. } \\
\text { end-expir. } \\
\text { pressure }\end{array}$ & $\begin{array}{l}\text { End-expir. } \\
\text { volume } \\
\text { change }\end{array}$ \\
\hline & $\min$ & $\min$ & $\% \mathrm{CO}_{2}$ & $m m \mathrm{Hg}$ & $\underset{\mathrm{Cm} / \mathrm{sec}}{\mathrm{H}_{2} \mathrm{O} /}$ & $\underset{\mathrm{H}_{2} \mathrm{O}}{\mathrm{ml} / \mathrm{cm}}$ & $\underset{\times 10^{6}}{\text { dyne-cm }}$ & $\begin{array}{c}\text { dyne-cm } \\
\times 10^{6}\end{array}$ & $\mathrm{~cm} \mathrm{H}_{2} \mathrm{O}$ & $m l$ \\
\hline 6 & $\begin{array}{r}15 \\
2 \\
3 \\
5 \\
9 \\
1.5\end{array}$ & $\begin{array}{r}0 \\
8 \\
18 \\
24 \\
34 \\
36\end{array}$ & $\begin{array}{l}\text { Air } \\
10 \\
\text { Air } \\
15 \\
\text { Air } \\
15\end{array}$ & $\begin{array}{l}23 \\
58 \\
24 \\
77\end{array}$ & $\begin{array}{l}2.69 \\
9.57 \\
3.16 \\
8.24 \\
2.15 \\
4.89\end{array}$ & $\begin{array}{l}17.8 \\
17.4 \\
18.2 \\
17.4 \\
17.4 \\
17.8\end{array}$ & $\begin{array}{l}0.96 \\
3.18 \\
1.10 \\
2.94 \\
0.88 \\
2.23\end{array}$ & $\begin{array}{l}5.66 \\
5.53 \\
5.66 \\
5.63 \\
5.70 \\
5.43\end{array}$ & $\begin{array}{l}1.0 \\
0.4 \\
1.2 \\
0.3 \\
1.0 \\
1.0\end{array}$ & $\begin{array}{c}0 \\
+25 \\
-35 \\
-15 \\
-50 \\
-35\end{array}$ \\
\hline 7 & $\begin{array}{r}15 \\
2 \\
6 \\
4 \\
2 \\
3\end{array}$ & $\begin{array}{c}0 \\
4 \\
8 \\
13 \\
15.5 \\
19\end{array}$ & $\begin{array}{l}\text { Air } \\
15 \\
15 \\
\text { Air } \\
15 \\
\text { Air }\end{array}$ & $\begin{array}{l}19 \\
95\end{array}$ & $\begin{array}{l}4.83 \\
4.17 \\
3.33 \\
3.33 \\
3.75 \\
2.92\end{array}$ & $\begin{array}{l}17.7 \\
19.6 \\
20.0 \\
20.4 \\
22.4 \\
20.4\end{array}$ & $\begin{array}{l}2.37 \\
1.90 \\
1.72 \\
1.45 \\
1.61 \\
1.43\end{array}$ & $\begin{array}{l}7.27 \\
6.66 \\
6.55 \\
6.45 \\
5.70 \\
6.84\end{array}$ & $\begin{array}{l}1.0 \\
0.0 \\
1.0 \\
1.5 \\
0.0 \\
1.5\end{array}$ & $\begin{array}{c}0 \\
-25 \\
0 \\
0 \\
-40 \\
-40\end{array}$ \\
\hline 8 & $\begin{array}{l}15 \\
1.5 \\
2.0 \\
3 \\
2.5 \\
5.5 \\
8\end{array}$ & $\begin{array}{l}0 \\
2.5 \\
3 \\
4 \\
7 \\
13.5 \\
22\end{array}$ & $\begin{array}{l}\text { Air } \\
10 \\
10 \\
10 \\
\text { Air } \\
10 \\
\text { Air }\end{array}$ & $\begin{array}{l}64 \\
34 \\
35\end{array}$ & $\begin{array}{r}6.25 \\
10.71 \\
13.75 \\
10.53 \\
7.02 \\
9.30 \\
9.65\end{array}$ & $\begin{array}{l}16.2 \\
14.2 \\
14.9 \\
14.5 \\
14.9 \\
15.8 \\
14.5\end{array}$ & $\begin{array}{l}0.92 \\
1.55 \\
1.86 \\
1.47 \\
0.98 \\
1.41 \\
1.43\end{array}$ & $\begin{array}{l}2.67 \\
3.02 \\
2.78 \\
2.98 \\
3.04 \\
2.98 \\
2.21\end{array}$ & $\begin{array}{l}1.0 \\
0.5 \\
1.5 \\
2.0 \\
1.5 \\
2.5 \\
1.5\end{array}$ & $\begin{array}{c}0 \\
+35 \\
+200 \\
+275 \\
+85 \\
+275 \\
0\end{array}$ \\
\hline 9 & $\begin{array}{c}15 \\
4.5 \\
2.5 \\
5.5 \\
6\end{array}$ & $\begin{array}{r}0 \\
5 \\
9 \\
15 \\
23\end{array}$ & $\begin{array}{l}\text { Air } \\
10 \\
\text { Air } \\
15 \\
\text { Air }\end{array}$ & $\begin{array}{l}32 \\
67 \\
97\end{array}$ & $\begin{array}{l}4.24 \\
8.47 \\
3.39 \\
8.47 \\
6.78\end{array}$ & $\begin{array}{l}13.2 \\
11.3 \\
12.5 \\
11.5 \\
11.8\end{array}$ & $\begin{array}{l}0.31 \\
2.10 \\
0.43 \\
1.06 \\
0.82\end{array}$ & $\begin{array}{l}2.49 \\
2.78 \\
2.49 \\
2.70 \\
2.65\end{array}$ & $\begin{array}{l}0.0 \\
0.0 \\
0.0 \\
0.0 \\
0.0\end{array}$ & $\begin{array}{c}0 \\
+75 \\
+25 \\
+60 \\
+10\end{array}$ \\
\hline 10 & $\begin{array}{c}15 \\
5 \\
6 \\
22 \dagger \\
7 \\
5\end{array}$ & $\begin{array}{r}0 \\
6 \\
13 \\
29 \\
37 \\
43\end{array}$ & $\begin{array}{l}\text { Air } \\
15 \\
\text { Air } \\
\text { Air } \\
15 \\
\text { Air }\end{array}$ & $\begin{array}{r}103 \\
26 \\
100\end{array}$ & $\begin{array}{l}1.54 \\
2.69 \\
1.54 \\
1.54 \\
1.54 \\
1.15\end{array}$ & $\begin{array}{l}33.3 \\
26.9 \\
33.3 \\
30.4 \\
30.4 \\
29.2\end{array}$ & $\begin{array}{l}0.69 \\
1.28 \\
0.78 \\
0.73 \\
0.69 \\
0.76\end{array}$ & $\begin{array}{l}2.13 \\
2.64 \\
2.16 \\
2.42 \\
2.55 \\
2.59\end{array}$ & $\begin{array}{l}2.0 \\
.75 \\
1.5 \\
1.5 \\
1.5 \\
2.0\end{array}$ & $\begin{array}{c}0 \\
+100 \\
+110 \\
+75 \\
+75 \\
+10\end{array}$ \\
\hline
\end{tabular}

* Abbreviations as in Table I.

$\dagger$ Atropine, $0.06 \mathrm{mg}$ per $\mathrm{kg}$, iv, 6 minutes before this determination. 
TABLE III

Effect of vagotomy in a ventilated dog*

\begin{tabular}{|c|c|c|c|c|c|c|c|}
\hline TTG & $T_{p} C$ & $\begin{array}{l}\text { Test } \\
\text { gas }\end{array}$ & Resistance & Compliance & $\begin{array}{c}\text { Nonelastic } \\
\text { work }\end{array}$ & $\begin{array}{c}\text { Elastic } \\
\text { work }\end{array}$ & $\begin{array}{l}\text { Transpulm. } \\
\text { end-expir. } \\
\text { pressure }\end{array}$ \\
\hline $\min$ & $\min$ & $\% \mathrm{CO}_{2}$ & $\underset{L / \mathrm{sec}}{\mathrm{cm} \mathrm{H}_{2} \mathrm{O} /}$ & $\underset{\mathrm{H}_{2} \mathrm{O}}{\mathrm{ml} / \mathrm{cm}}$ & $\underset{\times 10^{8}}{d y n e-c m}$ & $\begin{array}{c}\text { dyne-cm } \\
\times 10^{6}\end{array}$ & $\mathrm{~cm} \mathrm{H}_{2} \mathrm{O}$ \\
\hline $\begin{array}{l}15 \\
0.5 \\
1 \dagger \\
1.5 \ddagger \\
3 \\
7 \\
8 \ddagger \\
10\end{array}$ & $\begin{array}{l}0 \\
3.5 \\
4 \\
4.5 \\
6 \\
14 \\
15 \\
17\end{array}$ & $\begin{array}{l}\text { Air } \\
10 \\
10 \\
10 \\
10 \\
\text { Air } \\
\text { Air } \\
\text { Air }\end{array}$ & $\begin{array}{c}3.96 \\
11.58 \\
5.28 \\
18.18 \\
4.5 \\
3.0 \\
17.88 \\
3.24\end{array}$ & $\begin{array}{l}27.3 \\
22.2 \\
22.2 \\
18.2 \\
27.3 \\
26.1 \\
18.2 \\
31.6\end{array}$ & $\begin{array}{l}0.82 \\
2.33 \\
1.08 \\
3.50 \\
0.82 \\
0.67 \\
4.06 \\
0.61\end{array}$ & $\begin{array}{l}2.02 \\
2.35 \\
2.39 \\
2.63 \\
1.90 \\
2.18 \\
2.72 \\
1.76\end{array}$ & $\begin{array}{l}1.5 \\
0.5 \\
0.5 \\
1.5 \\
0.5 \\
1.5 \\
2.0 \\
1.6\end{array}$ \\
\hline
\end{tabular}

* Abbreviations as in Table I.

+ Vagus cut.

‡ Vagus stimulated by $15 \mathrm{v}, 100$ cycles per second.

statistically from the analysis. It also allows combination of the results from Tables I and II without any further adjustment of the data.

Preliminary analyses showed that in addition to the dog-to-dog variation, five terms in the regression equations were adequate to explain almost all the observed residual variation in the four dependent variables. These were: $\mathrm{pCO}_{2}$, natural logarithm of $\mathrm{pCO}_{2}\left(\ln \mathrm{pCO}_{2}\right), \mathrm{TpC}$, TTG interacting with $\mathrm{pCO}_{2}\left(\mathrm{TTG} \times \mathrm{pCO}_{2}\right)$, and $\mathrm{TpC}$ interacting with $\mathrm{pCO}_{2}\left(\mathrm{TpC} \times \mathrm{pCO}_{2}\right)$. The time the dog breathed the test gas appeared to have no direct effect on the four dependent variables, but had some effect only when considered together with the concentration of arterial $\mathrm{pCO}_{2}$.

Analysis of variance for resistance based upon these five factors plus the variation among dogs is shown in Table IV. The five factors plus the dog-to-dog variation accounted for 924.891/ $1,152.663=80.2 \%$ of the variability among all observations. The major source of variation, as expected, was the difference among dogs. The $\mathrm{F}$ ratio for this factor was significant at the $1 \%$ level. Despite the large variation among dogs, however, the direct effect of $\mathrm{pCO}_{2}$ upon resistance was highly significant, and the $\mathrm{F}$ ratio of 19.069 is associated with a probability beyond the $1 \%$ level. The other two significant factors were $\mathrm{TpC}$ and TTG $\times \mathrm{pCO}_{2}$. The latter was negative, indicating that at higher $\mathrm{pCO}_{2}$ long TTG would tend to lower resistance.

The effect of dog-to-dog, variation was much

TABLE IV

Analysis of variance for resistance*

\begin{tabular}{|c|c|c|c|c|}
\hline Source & $\begin{array}{l}\text { Degrees of } \\
\text { freedom }\end{array}$ & $\begin{array}{l}\text { Sum of } \\
\text { squares }\end{array}$ & $\begin{array}{c}\text { Mean } \\
\text { square }\end{array}$ & F ratio \\
\hline Total & 71 & $1,152.663$ & & \\
\hline $\begin{array}{l}\text { Regression on } \\
\text { all variables }\end{array}$ & 14 & 924.891 & 66.064 & 16.532 \\
\hline Dogs $\dagger$ & 9 & 471.815 & 52.424 & $13.119 \ddagger$ \\
\hline $\begin{array}{l}\mathrm{pCO}_{2} \text { and } \\
\ln \mathrm{pCO}_{2}\end{array}$ & 2 & 152.403 & 76.201 & $19.069 \ddagger$ \\
\hline $\mathrm{T}_{\mathrm{p}} \mathrm{C} \dagger$ & 1 & 18.230 & 18.230 & 4.5628 \\
\hline $\mathrm{pCO}_{2} \times \mathrm{TTG} \dagger$ & 1 & 35.996 & 35.996 & $9.008 t$ \\
\hline $\mathrm{pCO}_{2} \times \mathrm{T}_{\mathrm{p}} \mathrm{C} \dagger$ & 1 & 0.012 & 0.012 & 0.003 \\
\hline Residual error & 57 & 227.771 & 3.996 & \\
\hline
\end{tabular}

* Abbreviations as in Table I.

+ Values adjusted for other variables.

$\$$ Significant at $1 \%$ level.

$\$$ Significant at $5 \%$ level. 
TABLE V

Analysis of rariance for compliance*

\begin{tabular}{|c|c|c|c|c|}
\hline Source & $\begin{array}{l}\text { Degrees of } \\
\text { freedom }\end{array}$ & $\begin{array}{l}\text { Sum of } \\
\text { squares }\end{array}$ & $\begin{array}{c}\text { Mean } \\
\text { square }\end{array}$ & F ratio \\
\hline Total & 71 & $9,426.999$ & & \\
\hline $\begin{array}{l}\text { Regression on } \\
\text { all variables }\end{array}$ & 14 & $9,054.860$ & 646.776 & $99.066 \dagger$ \\
\hline Dogs & 9 & $7,976.202$ & 886.245 & $136.745 \dagger$ \\
\hline $\begin{array}{l}\mathrm{pCO}_{2} \text { and } \\
\ln \mathrm{pCO}_{2} \ddagger\end{array}$ & 2 & 86.716 & 43.358 & $6.641 \dagger$ \\
\hline $\mathrm{T}_{\mathrm{p}} \mathrm{C}$ & 1 & 8.827 & 8.827 & 1.352 \\
\hline $\mathrm{pCO}_{2} \times$ TTG $\ddagger$ & 1 & 1.678 & 1.678 & 0.257 \\
\hline $\mathrm{pCO}_{2} \times \mathrm{P}_{\mathrm{p}} \mathrm{C} \ddagger$ & 1 & 49.588 & 49.588 & $7.595 \dagger$ \\
\hline Residual error & 57 & 372.138 & 6.529 & \\
\hline
\end{tabular}

* Abbreviations as in Table I.

† Significant at $1 \%$ level.

† Values adjusted for other variables.

greater upon the observations of compliance than resistance, but the influence of $\mathrm{pCO}_{2}$ was nonetheless significant. Results are presented in Table V.

Because most of the variation among the compliance observations is attributed to the individual differences of the ten dogs, the model explained $9,054.860 / 9,426.999=96.1 \%$ of the variation. After adjustment for or removal of the individual effects, however, analysis shows that the influence of varying $\mathrm{pCO}_{2}$ upon compliance is still significant. The $\mathrm{F}$ ratio for the latter test is 6.641 and is significant at a level of less than $1 \%$. The only other significant term was $\mathrm{TpC} \times \mathrm{pCO}_{2}$; this was positive, so that compliance increased rapidly on very high levels of $\mathrm{pCO}_{2}$ at the end of the experiment on each dog.

Analyses of variance for viscous work and elastic work followed closely the patterns established for resistance and compliance, respectively. The least satisfactory but still adequate fit was obtained with the viscous work. Numerical results are given below for all four dependent variables, and include a constant term to account for dog-to-dog variations in base-line values. Resistance $=-0.223+0.0345 \mathrm{pCO}_{2}+1.562 \ln \mathrm{pCO}_{2}$ $-0.0561 \mathrm{TpC}-0.00306\left(\mathrm{TTG} \times \mathrm{pCO}_{2}\right)+0.00-$ $0020\left(\mathrm{TpC} \times \mathrm{pCO}_{2}\right) . \quad$ Compliance $=18.265-$ $0.1273 \mathrm{pCO}_{2}+4.339 \ln \mathrm{pCO}_{2}-0.0390 \mathrm{TpC}-$ $0.00066 \quad\left(\mathrm{TTG} \times \mathrm{pCO}_{2}\right)+0.001277 \quad(\mathrm{TpC} \times$ $\left.\mathrm{pCO}_{2}\right)$. Viscous work $=-0.633+0.0126 \mathrm{pCO}_{2}$
$+0.810 \ln \mathrm{pCO}_{2}-0.0241 \mathrm{TpC}-0.00123$ (TTG $\left.\times \mathrm{pCO}_{2}\right)+0.000015\left(\mathrm{TpC} \times \mathrm{pCO}_{2}\right) . \quad$ Elastic work $=7.648+0.0240 \mathrm{pCO}_{2}-1.055 \ln \mathrm{pCO}_{2}+$ $0.0075 \mathrm{TpC}+0.00029\left(\mathrm{TTG} \times \mathrm{pCO}_{2}\right)-0.000-$ $281\left(\mathrm{TpC} \times \mathrm{pCO}_{2}\right)$.

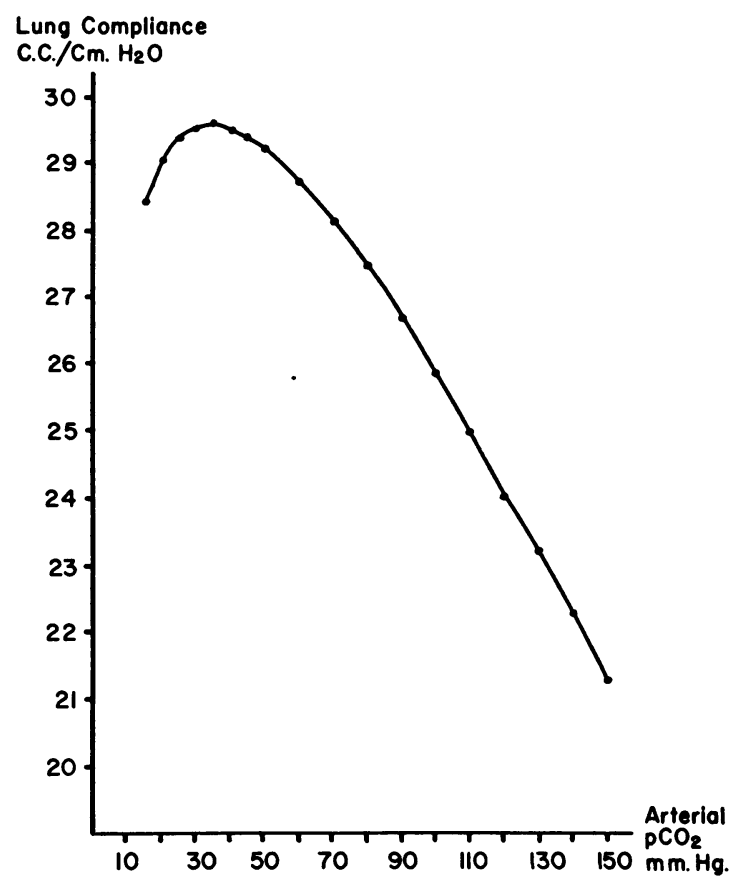

Fig. 2. Change in compliance as a function of $\mathrm{PCO}_{2}$. Effects of individual dogs, total time on the test gas $\times \mathrm{pCO}_{2}$, and total time after control run $\times \mathrm{pCO}_{2}$ were held constant. Data points are not included because the effects of factors listed above cannot be held constant. 
To summarize, analyses of variance showed that the models described were highly significantly related $(p<0.01)$ to the parameters of pulmonary mechanics. The joint effects of $\mathrm{pCO}_{2}$ and $\ln$ $\mathrm{pCO}_{2}$ were significant as follows : resistance, $\mathrm{p}<$ 0.01 ; compliance, $\mathrm{p}<0.01$; viscous work, $\mathrm{p}<$ 0.01 ; and elastic work, $\mathrm{p}<0.05$.

Other variables with significant effects on the parameters of lung mechanics were as follows. Resistance showed a significant $(p<0.05)$ tendency to decrease with $\mathrm{TpC}$. This was also true $(\mathrm{p}<0.01)$ if $\mathrm{pCO}_{2}$ was elevated for longer periods (TTG $\times \mathrm{pCO}_{2}$ ). Compliance and elastic work were both highly correlated $(p<0.01)$ with $\mathrm{TpC} \times \mathrm{pCO}_{2}$. For compliance, the regression coefficient was positive and for elastic work, negative. This means that the lung's distensibility at elevated $\mathrm{pCO}_{2}$ increased with the length of the experiment, whereas the elastic work decreased.

Figures 2, 3, and 4 plot the relationships expressed by these equations. The equation in each figure represents the pure relationship between the measured responses and the $\mathrm{pCO}_{2}$ after adjustment for other factors such as variation among dogs and time. For example, Figure 3 shows the change in resistance expected as arterial $\mathrm{pCO}_{2}$ is varied from 15 to $150 \mathrm{~mm} \mathrm{Hg}$ and is adjusted for the average dog effect as well as

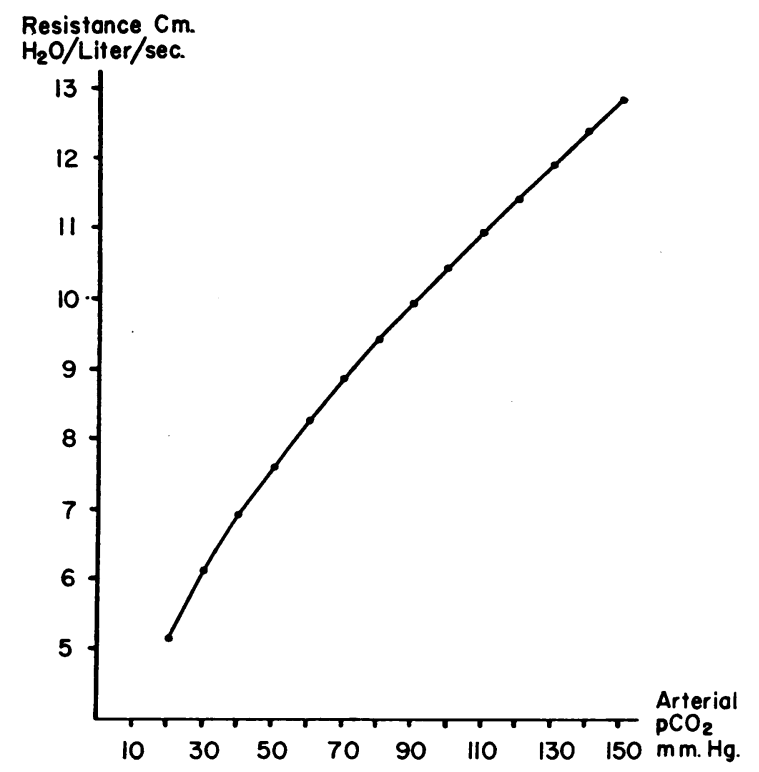

Fig. 3. Change in resistance as a function of $\mathrm{PCO}_{2}$. Same factors held constant as in Figure 3.

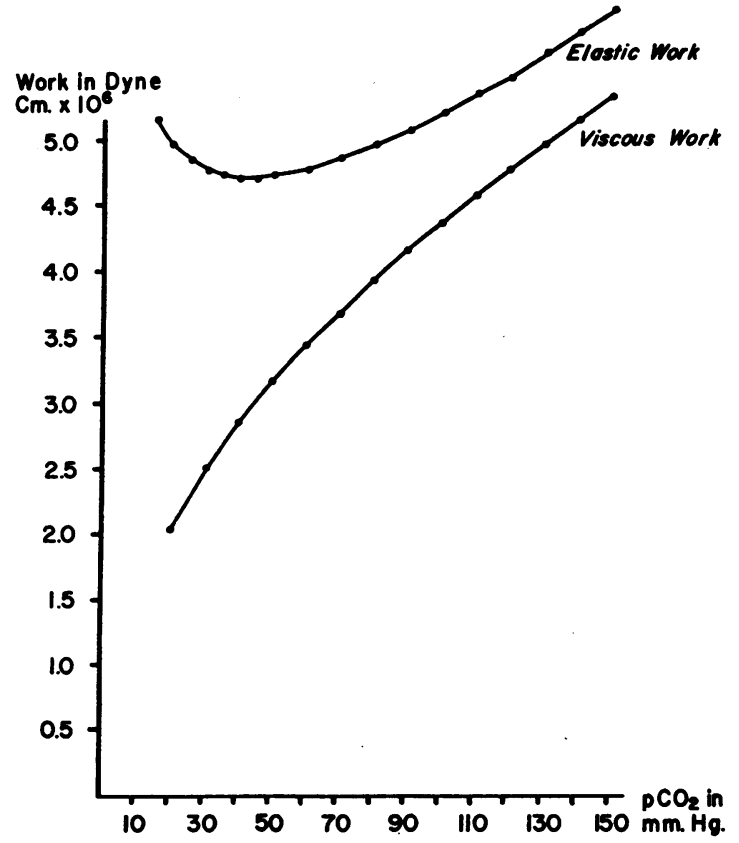

Fig. 4. Change in viscous and elastic work as A FUNCTION of $\mathrm{PCO}_{2}$. Corrected for same factors as in Figures 3 and 4.

TTG. Resistance steadily increased over the measured range of $\mathrm{pCO}_{2}$ about $2 \frac{1}{2}$ times. Compliance increased slightly until the $\mathrm{pCO}_{2}$ reached the normal range of 35 to 50 and then steadily fell. Viscous work increased $2 \frac{1}{2}$ times, but elastic work increased only $20 \%$.

\section{DISCUSSION}

Although the results clearly demonstrate an increase in resistance with hypercapnia under the conditions of these experiments, such changes may occur from a variety of causes. (Since animal size, position of respiration, tidal volume, and flow rate were different in individual dogs, the principal variation among all observations would be that from dog to dog. Flow rate and tidal volume were unaltered in the individual dogs. It is wellknown that airway resistance increases with change in the position of breathing toward a lower part of the respiratory curve. To ascertain that change in position of respiration toward a lower part of the respiratory curve was not increasing the resistance, the body plethysmograph was used in the last five experiments.) A transient, slight 
fall occurred in end-expiratory volume with $\mathrm{CO}_{2}$ breathing, and seems likely to be due to an acute change in $R Q$ owing to the dog's rapid uptake of $\mathrm{CO}_{2}$. The transient fall in volume was followed by an increase in volume on $\mathrm{CO}_{2}$ associated with an increase in resistance. This observation indicates that the alterations in respiratory mechanics reported here were due to a change in airway size, not to volume change alone. Changes observed with vagotomy confirm that some factor other than the volume change was effective.

Volume and pressure changes observed in these dogs seem best explained as follows. When the high concentration of $\mathrm{CO}_{2}$ was first administered, the base-line lung volume decreased transiently owing to rapid uptake of the $\mathrm{CO}_{2}$ by the tissues. As the bronchioles constricted, airway resistance increased markedly from the effect of $\mathrm{CO}_{2}$. Since flow rates remained unchanged, the difference between mean transpulmonary pressure during inspiration and expiration increased. The volumes of gas delivered and withdrawn remained fixed and equal, but the pressure in the pump cylinder during inflation tended to rise, and during deflation the cylinder pressure tended to fall. During the exhaust phase, the withdrawn gas was expelled into the atmosphere and at this pressure, occupied progressively less volume than the gas taken in for delivery to the animal's lungs. This explains the system's tendency to accumulate gas in proportion to the level of airway resistance. The expected accumulation was calculated from pump volume and the mean difference in inspiratory and expiratory transpulmonary pressures; the observed changes agreed closely with the calculated ones. This mechanism probably explains the system's tendency slowly to accumulate gas during long periods of ventilation with air. since the normal airway resistance had to be overcome

Changes in compliance were small and subject to error, since there was no pause in the pump on change from inspiration to expiration so that a difference between alveolar and mouth pressure could exist. The small increase in compliance could have been due to the increase in volume exceeding the limits of straight-line relationship between change in pressure and in volume. Unless dogs were at the upper limit of inspiratory reserve during the control periods, this seems unlikely.
The inherent inaccuracy in determination of compliance and elastic work when only two points on the compliance curve are known dictates caution in the interpretation of changes in elastic properties. These dynamic curves do, however, reflect accurately the resistive properties of the lungs.

The changes in nonelastic work with hypercapnia could be due to increased airway resistance or to increased tissue resistance. The methods of this study cannot distinguish between the effects of narrowed airway lumen and the decreased pliability of the lung tissues. The combination, however, of increased lung volume and decreased endexpiratory pressure after the administration of $\mathrm{CO}_{2}$ can best be explained by air trapping in the distal portion of the lungs as a result of constricted airways. In earlier studies where the lungs were allowed to empty themselves during the expiratory phase, massive air trapping occurred when $\mathrm{CO}_{2}$ was administered. Kilburn (7) and Roy and Brown (6) have shown that bronchial lumen decreases in response to hypercapnia in the intact animal. It is unlikely that the change is due to alteration of pulmonary vascular tone, since $\mathrm{CO}_{2}$ does not effect this in dogs (12).

These changes in mechanics are not the result of a local effect on the lung. Daly and coworkers (3) clearly demonstrated in cross-circulation experiments in dogs that this was a central reflex and that the vagus nerve had to be intact. Previous experiments (5) and the present findings confirm that this is a vagal reflex. The observed effect of hypercapnia on pulmonary mechanics seems on the surface to be at variance with certain observations suggesting the bronchodilator effect of $\mathrm{CO}_{2}$. Since the studies of Nisell (8) were on isolated lungs, any reflex bronchoconstriction of the type reported here would not have been in effect. Severinghaus and associates (13) observed unilateral bronchoconstriction associated with occlusion of one pulmonary artery. Since administration of $\mathrm{CO}_{2}$ reversed this, they concluded that low alveolar $\mathrm{pCO}_{2}$ causes bronchoconstriction. Since arterial $\mathrm{pCO}_{2}$ would not have been altered in these experiments, the bronchoconstrictive effect of hypercapnia would be absent. In their experiments, unilaterial pulmonary artery occlusion had little effect on ventilation under chloralose anesthesia. To establish that 
the alterations in lung mechanics seen in our dogs were not due to the pharmacologic effects of chloralose, a study was done under pentobarbital anesthesia. The changes observed were similar in magnitude and direction to those seen with chloralose anesthesia.

Attinger (9) reported in dogs that during spontaneous breathing, 5 and $10 \% \mathrm{CO}_{2}$ caused an increase in functional residual capacity of 90 to 100 $\mathrm{ml}$ and some increase in the lung's compliance. The airway resistance rose slightly, although Attinger postulated that this was no more than would be expected with the increased flow rate and decreased functional residual capacity. Since the airway resistance was calculated by the method of Cook and co-workers (11), an upward change in mid-position of respiration may have occurred owing to a greater inspiratory volume. If this was the case, a change in respiratory work per unit of ventilation might have been obscured. Butler and associates (10) used the body-plethysmographic method to measure airway resistance in human subjects during rapid panting respiration after up to 10 minutes of breathing 4 to $10 \%$ $\mathrm{CO}_{2}$. There was no change in position of ventilation, and the effect on airway resistance was variable. Arterial $\mathrm{pCO}_{2}$ was not determined. Their failure to show a consistent increase in viscous resistance may have been due to the method used. In our studies, it was not clear whether elevated $\mathrm{pCO}_{2}$, total $\mathrm{CO}_{2}$, or depressed $\mathrm{pH}$ was principally responsible for the alterations in lung mechanics, since all changed simultaneously. Arterial $\mathrm{pCO}_{2}$ was chosen arbitrarily as the independent variable since it was directly altered. Further investigation will be necessary to determine the importance of the changes in $\mathrm{pH}$ and the total $\mathrm{CO}_{2}$ content.

If these acute experiments are valid examples of the response to be expected, then certain clinical implications are suggested. The work of Sealy, Young, and Harris (14) and Young, Monroe, and Craige (15) has demonstrated that a rapid fall in arterial $\mathrm{pCO}_{2}$ may be associated with serious cardiac arrhythmias and often, ventricular fibrillation. In such situations, bronchoconstriction associated with hypercapnia might be visualized as a mechanical buffer against a rapid decrease in tissue $\mathrm{pCO}_{2}$. Despite the possible usefulness of this reflex, it has certain obvious de- leterious effects. Acute and chronic respiratory acidosis is being recognized more and more frequently in clinical situations. Acute respiratory acidosis often occurs in postoperative periods, particularly after open-heart surgery and major pulmonary resections. Chronic respiratory acidosis most often occurs in patients with pulmonary emphysema, and acute, severe $\mathrm{CO}_{2}$ retention may result from complicating infections. Since all of these situations are associated with elevated arterial $\mathrm{pCO}_{2}$, if bronchoconstriction resulted from hypercapnia, increased work would be required of the respiratory system to maintain ventilation at a time when the patient could ill afford it. A number of investigators (16-19) have shown that the ventilatory response to $\mathrm{pCO}_{2}$ decreases when the work required for a given level of ventilation increases. Thus, an increase in the viscous work of breathing associated with hypercapnia would lead to less than the normal increase in alveolar ventilation, thereby resulting in a vicious cycle leading to further elevation of $\mathrm{pCO}_{2}$ and further decrease in efficiency of the ventilatory effort. These interactions offer one explanation for progressive, severe respiratory acidosis. The association of these two phenomena also explains how mechanical ventilation can, by correcting hypercapnia, restore respiratory compensation and enable the patient to maintain this compensation unassisted (20). If this increase in airway resistance depends on a change in $\mathrm{pH}$ as much as on $\mathrm{pCO}_{2}$, metabolic acidosis after major cardiac or pulmonary surgery might be the initiating factor in the development of acute, postoperative respiratory failure.

\section{SUM MARY}

In dogs with opened chest and controlled respiration, an increase in $\mathrm{CO}_{2}$ in the inspired air decreased compliance and increased elastic work, resistance, and viscous work; the increase in viscous work was $2 \frac{1}{2}$ times that of the elastic work. Vagotomy prevented these changes.

\section{ACKNOWLEDGMENT}

We are indebted to Dr. Bernard G. Greenberg of the Department of Biostatistics in the School of Public Health, The University of North Carolina, for the statistical analysis of the data reported. 


\section{REFERENCES}

1. Einthoven, W. Uber die Wirkung der Bronchialmuskeln nach einer neuer Methode untersucht, und uber Asthma nervosum. Pflügers Arch. ges. Physiol. 1892, 51, 367.

2. Dixon, W. E., and T. G. Brodie. Contributions to the physiology of the lungs; Part I : The bronchial muscles, their innervation, and the action of drugs upon them. J. Physiol. (Lond.) 1903, 29, 97.

3. Daly, M. deB., C. J. Lambertsen, and A. Schweitzer. The effects upon the bronchial musculature of altering the oxygen and carbon dioxide tensions of the blood perfusing the brain. J. Physiol. (Lond.) 1953, 119, 292.

4. Konsett, H., and R. Rössler. Versuchsanordnung zu Untersuchungen an der Bronchialmuskulatur. Naunyn-Schmiedeberg's Arch. exp. Path. Pharmak. 1940, 195, 71.

5. Peters, R. M. Relationship between per cent of carbon dioxide in inspired air and degree of bronchoconstriction. Ann. Surg. 1955, 142, 461.

6. Roy, C. S., and G. Brown. On bronchial contraction. J. Physiol. (Lond.) 1885, 6, xxi.

7. Kilburn, K. H. Dimensional responses of bronchi in apneic dogs to airway pressure, gases and drugs. J. appl. Physiol. 1960, 15, 229.

8. Nisell, O. I. The action of oxygen and carbon dioxide on the bronchioles and vessels of the isolated perfused lungs. Acta physiol. scand. 1950, 21, suppl. 73.

9. Attinger, E. O. Pulmonary mechanics and hemodynamics during changes in ventilation and blood volume. J. appl. Physiol. 1960, 15, 429.

10. Butler, J., C. G. Caro, R. Alcala, and A. B. DuBois. Physiological factors affecting airway resistance in normal subjects and in patients with obstructive respiratory disease. J. clin. Invest. 1960, 39, 584.
11. Cook, C. D., J. M. Sutherland, S. Segal, R. B. Cherry, J. Mead, M. B. McIlroy, and C. A. Smith. Studies of respiratory physiology in the newborn infant. III. Measurements of mechanics of respiration. J. clin. Invest. 1957, 36, 440.

12. Peters, R. M. Effect of unilateral carbon dioxide breathing on pulmonary blood flow. Amer. J. Physiol. 1957, 191, 399.

13. Severinghaus, J. W., E. W. Swenson, T. N. Finley, M. T. Lategola, and J. Williams. Unilateral hypoventilation produced in dogs by occluding one pulmonary artery. J. appl. Physiol. 1961, 16, 53.

14. Sealy, W. C., W. G. Young, Jr., and J. S. Harris. Studies on cardiac arrest: the relationship of hypercapnia to ventricular fibrillation. J. thorac. Surg. 1954, 28, 447.

15. Young, D. T., E. W. Monroe, and E. Craige. Relationship between cardiac toxicity of $\mathrm{K}$ and acute alterations of blood $\mathrm{pH}$ and $\mathrm{pCO}_{2}$. Amer. J. Physiol. 1960, 199, 759.

16. Richards, D. W., H. W. Fritts, Jr. and A. L. Davis. Observations on the control of respiration in emphysema: the effects of oxygen on ventilatory response to $\mathrm{CO}_{2}$ inhalation. Trans. Ass. Amer. Phycns 1958, 71, 142.

17. Brodovsky, D., J. A. MacDonnell, and R. M. Cherniack. The respiratory response to carbon dioxide in health and in ephysema. J. clin. Invest. 1960, 39, 724.

18. Cherniack, R. M., and D. P. Snidal. The effect of obstruction to breathing on the ventilatory response to $\mathrm{CO}_{2}$. J. clin. Invest. 1956, 35, 1286.

19. Barnett, T. B., and R. M. Peters. Studies on the mechanism of oxygen-induced hypoventilation: an experimental approach. J. clin. Invest. 1962, 41, 335.

20. Peters, R. M., T. B. Barnett, and R. Zeppa. An etiology of acute respiratory acidosis. J. thorac. Surg. 1961, 42, 445. 